\title{
The diversity of education in pathology worldwide and perspectives of the International Academy of Pathology
}

\section{George Kontogeorgos}

National and Kapodistrian University of Athens, Greece

Key words: special education, pathology, International Academy of Pathology.

Pathologia 2020; 17 (3), 282-286

*E-mail: gkonto@med.uoa.gr

The article, based on the personal experience of the President of the International Academy of Pathology (IAP), presents the features of three main training programs for pathologists: European, Anglo-Saxon and North-American, applied in accordance with the guidelines of the European Union of Medical Professionals (UEMS), the Royal College of Pathologists (RCPath) and the American Board of Pathology (ABPath), respectively.

Differences in the training of pathologists in different countries are associated with the structure and time of training, the possibilities of financing it, the sub-specialties of pathologists and their accreditation by the commissions for pathology. The minimum training time for pathologists varies in different countries of the world and is: six years (in Sri Lanka), five and a half years (in the countries of the British Commonwealth), four years (in the USA, North American countries, EU countries, Norway, Switzerland, Turkey, Australia, New Zealand), three to five years (in South Africa), two years (in Russia, Armenia, Mongolia, Vietnam, Cambodia), one year (in Ukraine).

The structure of training for resident pathologists is also different. For example, the European system of training pathologists covers such compulsory subjects as clinical and surgical pathology, autopsy, cytopathology, as well as additional (for some sub-specialties) educational disciplines: neuropathology, dermatopathology, pediatric pathology. The Anglo-Saxon system, in addition to clinical and surgical pathology, includes chemical pathology (metabolic medicine), virology, infectious diseases, and optional subjects: hematopathology and biochemistry. Medical microbiology and chemical pathology are also being studied in Arab countries. The North American resident pathologist training system includes surgical pathology, autopsy, forensic medical examination, chemistry, cytopathology, cytogenetics, molecular diagnostics, hematopathology, dermatopathology, neuropathology, virology, infectious diseases, liver pathology, transplant pathology, transfusion medicine. The financial support provided by the Education Committee of the IAP encourages the development of educational programs and the creation of schools in pathology in developing countries, the organization of international Congresses, teleconferences and webinars, and the development of the international program "Goodwill / Visiting / Ambassador". In conclusion, Albert Einstein's statement is given: "Education is not the learning of facts, but the training of the mind to think".

Conclusion. The time has come for an educational revolution. It is necessary to give strength to everyone in order to open channels everywhere to improve education and achieve harmonization of Pathology globally.

Киючові слова: спеціальна освіта, патологія, Інтернаціональна академія патології.

Патологія. 2020.

T. 17, № 3(50).

C. $282-286$

\section{Різноманіття освіти з патології у світі та перспективи Міжнародної академії патології}

\section{АЖордЖ Контогеоргос}

На підставі власного досвіду президента Міжнародної академії патології (IAP) наведені особливості трьох основних програм підготовки фахівців-патологів: європейської, англосаксонської та північноамериканської, - що застосовуються відповідно до основних принципів Європейського союзу медичних спеціалістів (UEMS), Королівського коледжу патологів (RCPath) та Американської ради патології (ABPath) відповідно.

Відмінності в підготовці патологів у різних країнах пов'язані зі структурою та часом навчання, можливостями фінансування, субспеціальностями патологів та їхньою акредитацією комісіями з патології. Мінімальний термін навчання патологів різний у різних країнах світу становить 6 років у Шрі-Ланці, 5,5 року - у країнах Британської Співдружності, 4 роки - у США, північноамериканських країнах, країнах ЄС, Норвегії, Швейцарії, Туреччині, Австралії, Новій Зеландії, 3-5 років - у країнах Південної Африки, 2 роки - у РФ, Вірменії, Монголії, В'єтнамі, Камбоджі, 1 рік - в Україні.

Відрізняється також структура навчання резидентів-патологів. Наприклад, європейська система підготовки патологів охоплює такі обов'язкові предмети, як клінічна та хірургічна патологія, аутопсія, цитопатологія, а також додаткові (для деяких субспеціальностей) навчальні дисципліни: нейропатологію, дерматопатологію, дитячу патологію. Англосаксонська система, крім клінічної та хірургічної патології, включає хімічну патологію (метаболічну медицину), вірусологію, інфекційні захворювання та фракультативні предмети: гематопатологію та біохімію. В арабських країнах вивчають також медичну мікробіологію та хімічну патологію. Північноамериканська система навчання резидента-патолога включає хірургічну патологію, аутопсію, судово-медичну експертизу, хімію, цитопатологію, цитогенетику, молекулярну діагностику, гематопатологію, дерматопатологію, нейропатологію, вірусологію, інфекційні захворювання, патологію печінки, патологію трансплантата, трансфузійну медицину.

Висвітлено фінансову підтримку, яку надає Комітет з освіти IAР у розвиток освітніх програм і створення шкіл із патології у країнах, що розвиваються; в організацію міжнародних конгресів, телеконференцій і вебінарів; у розвиток міжнародної програми «Доброзичливість / Візит / Посол» («Goodwill / Visiting / Ambassador»). На завершення наведено висловлювання Альберта Ейнштейна: «Освіта - це не вивчення фрактів, а підготовка розуму до мислення».

Висновки. Настав час для освітньої революції, потрібно дати сили всім та кожному, щоб усюди відкрити канали для поліпшення освіти, глобальної гармонізації патології. 


\section{Многообразие образования по патологии в мире и перспективы Международной академии патологии}

\section{Ажордж Контогеоргос}

На основании личного опыта президента Интернациональной академии патологии (IAР) представлены особенности трех основных программ подготовки специалистов-патологов: европейской, англосаксонской и североамериканской, - применяемых в соответствии с руководящими принципами Европейского союза медицинских специалистов (UEMS), Королевского колледжа патологов (RCPath) и Американского совета патологии (ABPath) соответственно.

Различия в подготовке патологов в разных странах связаны со структурой и временем обучения, возможностями его финансирования, субспециальностями патологов и их аккредитацией комиссиями по патологии. Минимальный срок обучения патологов разный в разных странах мира и составляет 6 шесть лет в Шри-Ланке, 5,5 года - в странах Британского содружества, 4 года - в США, североамериканских странах, странах ЕС, Норвегии, Швейцарии, Турции, Австралии, Новой Зеландии, 3-5 лет - в странах Южной Африки, 2 года - в РФ, Армении, Монголии, Вьетнаме, Камбодже, 1 год - в Украине.

Отличается также структура обучения резидентов-патологов. Например, Европейская система подготовки патологов охватывает такие обязательные предметы, как клиническая и хирургическая патология, аутопсия, цитопатология, а также дополнительные (для некоторых субспециальностей) учебные дисциплины: нейропатологию, дерматопатологию, детскую патологию. Англосаксонская система, кроме клинической и хирургической патологии, включает химическую патологию (метаболическую медицину), вирусологию, инфекционные заболевания и фракультативные предметы: гематопатологию и биохимию. В арабских странах также изучают медицинскую микробиологию и химическую патологию. Североамериканская система обучения резидента-патолога включает хирургическую патологию, аутопсию, судебно-медицинскую экспертизу, химию, цитопатологию, цитогенетику, молекулярную диагностику, гематопатологию, дерматопатологию, нейропатологию, вирусологию, инфекционные заболевания, патологию печени, патологию трансплантата, трансфузиионную медицину.

Показана финансовая поддержка, которую оказывает Комитет по образованию Интернациональной академии патологии в развитие образовательных программ и создание школ по патологии в развивающихся странах; в организацию международных конгрессов, телеконференций и вебинаров; в развитие международной программы «Доброжелательность / Визит / Посол» («Goodwill / Visiting / Ambassador»). В завершение приведено высказывание Альберта Эйнштейна: «Образование - это не изучение фактов, а подготовка разума к мышлению».

Выводы. Настало время для образовательной революции, нужно дать силы всем и каждому, чтобы повсюду открыть каналы для улучшения образования и глобальной гармонизации патологии.

Education is a systematic teaching process, which aims to raise interest and inspiration for knowledge and rational thought, and to develop intelligence by obtaining the necessary training on the basic principles and rules of a cognitive subject. As a rule, education is the process of acquiring knowledge and skills by attending a formal school, college or university. The rapid technological progress, which has caused a huge impact on all aspects of modern civilization, has also unsurprisingly affected education.

In parallel to Anatomy, Pathology has developed from the early studies by Leonardo da Vinci, Galen, Michelangelo and Andreas Vesalius. The knowledge of Anatomy has gradually provided detailed description of organ and tissue alterations, thus contributing and helping establish Anatomic Pathology. The specialty evolved alongside surgery, the use of microscope, histochemical stains, etc. The dramatic evolution of Pathology during the recent decades is attributed to the rapid advances in diagnostics, including applications of immunohistochemistry and molecular techniques.

During my 10-year tenure as Executive Board Member of the International Academy of Pathology (IAP) and for the last two years as President, I traveled to many countries, mostly outside of Europe and North America. I had the chance to participate in educational activities, to meet with many pathologists and acquire knowledge about education in pathology, which I found heterogeneous across the globe, due to the extensive knowledge spectrum of this specialty. Most differences relate to the structure of training, duration, funding, sub-specialties and accreditation of title of specialty, awarded by the boards of Pathology in different countries.

The main training programs for obtaining the title of specialty in Pathology and issuing license for practicing are three: The European, the Anglo-Saxon and the North-American, applied in accordance with the guidelines of the Union of European Medical Specialiats (UEMS) [1], the Royal College of Pathologists (RCPath) [2] and the American Board of Pathology (ABPath) [3], respectively.

The European system is implemented in accordance with UEMS guidelines for EU and EFTA (European Free Trade Association) countries. The UEMS council includes representatives from the EU, Norway, Switzerland and Turkey. Specialization in Pathology encompasses the following subjects: Surgical Pathology, Autopsy and Cytopathology. The minimum resident's training time is 4 years. In addition, there are some subspecialties requiring additional training, such as Neuropathology, Dermatopathology, Pediatric and Forensic Pathology. In the majority of the Balkan and Eastern European countries the educational system of the resident's training program is more or less in accordance with the UMS regulations.

The minimum training time for a pathologist in Russia is two years (residency) [4], in Ukraine - one year (internship) [5]. At this time, the doctor receives basic knowledge of pathological anatomy at the University department and practical training at the pathologoanatomical department of the clinical hospital. In further work in Ukraine, a pa-
Ключевые слова: специальное образование, патология, Интернациональная академия патологии.

Патология. 2020. T. 17, № 3(50).

C. $282-286$ 
thologist is obliged to take advanced training courses and pass the qualifying exam at the Academy of Postgraduate Education every three years, there is an opportunity to improve his diagnostic qualifications in a two-four-year clinical residency [5]. The sub-specialization of pediatric pathological anatomy has been accepted. A pathologist in Ukraine and Russia performs pathomorphological diagnostics of biopsies and surgical material, as well as pathological autopsies of deceased patients; forensic pathology is handled by doctors - forensic medical experts. In Ukraine and RF, cytology is separated from pathological diagnostics, cytological diagnostics is carried out by cytologists of clinical laboratories of hospitals.

The Anglo-Saxon educational system is mostly in accordance with the UEMS guidelines. In addition to Surgical Pathology the system includes: Chemical Pathology (Metabolic Medicine) and Medical Microbiology or Virology and Infectious Diseases (CIT). The duration of a resident's training is $5-51 / 2$ years which includes 2 out of 3 optional items (Microbiology, Hematology and Biochemistry) for obtaining the title of FRCPath [6]. Chemical Pathology and Microbiology are also applied in most British Commonwealth Nations and additionally in Arab countries. In some of these countries, in the examinations for the FRCPath qualification degree, a representative examiner of the Royal College of Pathologists of the UK participates.

For accreditation of specialty title from the American Board of Pathology, the North American education system combines Anatomic with Clinical Pathology. The resident's training includes: Twenty-five months in Anatomic Pathology, 18 months in Clinical Pathology and 5 months in a selective topic, totaling 48 months. The training in Pathology includes 15 months Surgical Pathology, 3 months Autopsies, 1 month Forensics, 3 months Cytopathology, 2 months Dermatopathology and 1 month Neuropathology, totally 25 months. The training in Clinical Pathology includes: one month Chemistry, 1 month Cytogenetics, 4 months Laboratory Hematology - Hematopathology, 1 month Liver Pathology, 1 month Medical Kidney - Transplant Pathology, 2 months Microbiology, 1 month Molecular Diagnostics, 2 months Transfusion Medicine and 5 months Senior rotations, totally 18 months [7]. However, due to the evolution of diagnostics and training requirements there are several ongoing updates. Cytopathology is an integral part of education and exercise in Pathology. In Europe and North America, qualified technicians screen the PAP test smears and the abnormal slides are forwarded to expert pathologists, who are responsible to make diagnoses and have the authorization to sign the reports. In the UK, the training time of pathologist residents in PAP test is progressively reduced due to its replacement by the National screening HPV DNA test program. As a result, there is a shortage of position for technicians - PAP test screeners, who are reassigned to other laboratory disciplines. In the Anglo-Saxon and North American countries, Clinical Chemistry is in danger of extinction, because this part of the practice is gradually invaded by $\mathrm{PhD}$ holders.

Regarding the education in pathology, there are several differences among other countries. The training in Brazil lasts for 3 years and there are preliminary examinations for candidates. For example, in the year 2018 there were 8 candidates for 4 positions. As it happens in many other countries, trainees have to pay tuition fees. The pathology training in Sri Lanka includes Surgical Pathology, Autopsies and Cytology, and the duration is 6 years. No official subspecialty exists. After the $2^{\text {nd }}$ year of training, the residents are tested to obtain the Diploma in Pathology. After the $6^{\text {th }}$ year, they undergo examinations to obtain the title of MD in Pathology. To get a position as senior registrar, one additional year of training abroad (UK, USA or Australia) is required. Malaysia discourages training abroad, because many pathologists stay permanently abroad once offered a position and never come back to their country. As a rule, European and North American countries are in favor of receiving trained pathologists, thus saving money for education, which is costly. Pathology training in Australia and South Pacific Islands is difficult, for these are remote islands, are many miles far from Australia and New Zealand and transportation is very difficult. For Diploma in Pathology 2 years training are required and for Master Diploma in Pathology another 2 years. There is a dramatic shortage of specialized pathologists in this area: currently, there are 10 residents and 6 specialized pathologists in Fiji Islands, and 1 Pathologist in each of Samoa and Tonga Islands. Pathology in sub-Saharan Africa is very diverse. There are 9 Universities in South Africa, and 1 University each in Botswana, Namibia, Zambia, Malawi, 2 Universities in Zimbabwe, whereas none in Swaziland and Lesotho. Depending on the country, the resident training program lasts 3-5 years. For South Africa the specialist title is: FRCPath (College of Pathology, South Africa) [8]. In this country, there are 160 registered Anatomic Pathologists for about 50 million populations, only 50 of them employed in the public sector. The pathology training in countries, such as Vietnam, Cambodia, Armenia and Mongolia lasts only 2 years and trainees have to pay a tuition fee.

Continuous developments of techniques and methods in cell and tissue diagnostics, as well as the introduction of new entities in the classification of neoplasms, have contributed to the enrichment of the knowledge spectrum of Pathology. Therefore, continuous education that maintains competence and learning about new developing areas has become mandatory. For this reason, in addition to formal studies, alternative education has to play a dynamic role. "Alternative education" refers to a teaching and learning system that is inconsistent with the standard curriculum of knowledge. The necessity arose from the specter of communities with particular social habits or religious orientations evolving along completely different tangents than the widely accepted mainstream. Alternative Education can be considered to be the education provided by religious, or even musical, schools which are associated with a number of specific approaches to teaching and learning. While considered "alternative education systems" today, they have existed since ancient times with the Peripatetic School by Aristotle being the most representative classical example. The Peripatetic School was founded by Aristotle in 335 B.C. in Greece along the lines of the Athens School of Plato. At the School of Plato, all candidates were eligible for admission, apart from those who were "ignorant in geometry", according to the inscription on the lintel: "MH $\triangle \mathrm{EI} \Sigma \mathrm{A} \Gamma \mathrm{E} \Omega \mathrm{METPHTO} \Sigma$ 


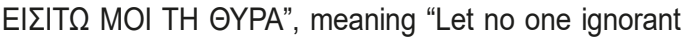
of geometry enter". In the famous fresco of Rafael "The School of Athens", Aristotle and Plato, together with the stoic Socrates, the nihilist Diogenes, the atheist Epicurus, the polymath Averroes (Ibn Rushd) and others were symbolically illustrated; all of them were eligible to enter the School of Athens.

We believe the time has come for an educational revolution, in order to give power and strength to everyone, by opening more channels, in order to improve education and harmonization of Pathology globally and make it possible everywhere. As it is true nowadays, continuing education is desirable by and applicable to all. This concept that incorporates a wide variety of learning tools and systems it is considered as lifelong learning. Congresses, conferences, and other educational activities such as lessons, slide seminars, short and long courses, etc. could be considered as parts of the alternative education. However, some questions remain: "Do all pathologists have the chance to attend"? "How can countries not developed in Pathology be assisted"? The IAP is generous by allocating and distributing funds through the Education Committee to support a wide range of educational activities and programs for developing countries, mostly those that are undeserved in Pathology [9]. IAP provides assistance for organizing local conferences, it develops schools of Pathology in third-world countries, allocates funds for individual pathologists and financing the Goodwill / Visiting I Ambassador Program. In addition, IAP is very keen in encouraging webinars.

The procedure for setting up congresses, financially supported by the IAP Education Committee, is as follows: The Congress is organized in a country moderated by an IAP Division. Among the invited speakers, internationally recognized pathologists are included to give plenary and keynote lectures, thus providing updates and new information on the areas of their expertise. The local pathologists are encouraged and motivated to participate. In addition, business meetings and workshops taking place during the conference which discuss and propose ways to improve education are welcomed.

Schools of Pathology have been established by the British Academy of Pathology in Bosnia, Sri Lanka and the Arab region. The necessity arose from the inability of women pathologists originating from these countries to travel unaccompanied to England.

The IAP Goodwill / Visiting / Ambassador program is a very important educational tool [10]. The procedure is as follows: An expert pathologist visits a country of IAP Division or a country of a not yet formed Division. The nominated pathologist offers educational activities on the topics of his/her expertise, in a way that addresses the needs of the visited country. The nominated pathologist is free to develop and propose a custom-fit, intensive training program, also undertaking other parallel activities, such as consultation on selected cases, technical assistance and anything else needed by the pathologists of the visited country. The visit lasts 4-6 days.

Other ways of support by the IAP include bursaries, mostly to junior pathologists to cover travel and accommodation cost for attending an International Congress of the IAP (necessary requisition is to submit an abstract) and reduced registration fee to all IAP members. Finally, IAP welcomes new National Divisions, encouraging third-world countries to increase the time of training in Pathology to 4 years in order to be eligible to form their own IAP Division. In addition, the use of modern educational tools, including teleconferences and webinars are encouraged. There are several advantages with these instrumental facilities, including real-time broadcasting, direct contact with the presenter by a web camera and communication through a chat-room. The individuals, who participate can store and archive the presentations in their computer to retrieve them later-on or review the slides anytime. The benefits for the attendees are important. The attendance is open to invited subscribers, no registration fee is required, there is real-time active participation, and the participants can raise questions and actively join in the discussion. Finally, but the most importantly, there is no cost for travel and accommodation.

It seems reasonable to assume that the time has come for an educational revolution, in order to give power and strength to everyone, by opening more channels to improve education and harmonize Pathology, in order to make it possible everywhere. Harmonization of Pathology around the globe is desirable, in order to achieve free movement of pathologists without borders and without need for additional proficiency examinations for accreditation of an acquired specialty title. However, the achievement of this goal is a hope for the future. Nevertheless, it is important to keep always in mind the saying of Albert Einstein: "Education is not the learning of facts, but the training of the mind to think".

Conflicts of interests: author has no conflict of interests. Конфлікт інтересів: віАсутній.

Надійшла Ао редакції / Received: 14.08.2019

Після Аоопрацювання / Revised: 09.10.2020

Прийнято Ао Аруку / Accepted: 12.10.2020

Information about the author:

Kontogeorgos George, MD, PhD, Professor, Research Associate at the Department of Pathophysiology, National and Kapodistrian University of Athens, Greece; Visiting Professor at the University of Toronto, Canada.

\section{Відомості про автора:}

Контогеоргос АжорАж, А-р меА. наук, професор, науковий співробітник каф. патологічної фізіології, Афінський національний університет імені Каподистрії, Греція; запрошений професор Університету Торонто, Канада.

\section{Сведения об авторе:}

Контогеоргос АЖорАж, А-р меА. наук, профессор, научный сотрудник каф. патологической физиологии,

Афинский национальный университет имени Каподистрии, Греция; приглашенный профессор Университета Торонто, Канада.

\section{References}

[1] European Union of Medical Specialists (UEMS). https://www.uems.eu/

[2] Royal College of Pathologists. https://www.rcpath.org/

[3] American Board of Medical Specialties. (n.d.). American Board of Pathology . https://www.abms.org/member-boards/contact-an-abmsmember-board/american-board-of-pathology/ 
[4] Balakhonov, A. V., Maevskaya, V. A., Stroev, Yu. I., Khanikatt, S. G., \& Churilov, L. P. (2009). Rossiiskoe i zarubezhnoe meditsinskoe obrazovanie: Bolonskii protsess i nash opyt [Russian and Foreign Medical Education: Bologna's Process and OurExperience]. Akkreditatsiya $v$ obrazovanii, (30), 26-35. [in Russian]

[5] Ukrainian Medical Council. Medical education in Ukraine. https://mcu. org.ua/medicinskoe-obrazovanie-v-ukraine/

[6] The Royal College of Pathologists. (n.d.). Examinations. https://www. cpath.org/trainees.htm

[7] Duke University School of Medicine. (n.d.). Residency program. Duke Pathology. https://pathology.duke.edu/education/residency-program

[8] The Colleges of Medicine of South Africa. (n.d.). The College of Pathologists: C PATH (CMSA). https://www.cmsa.co.za/view college. aspx?collegeid $=17$

[9] Dahlstrom, J. (2020, March). IAP Education. The International Academy of Pathology. https://www.iapcentral.org/current-activities/iap-education-chair-home-page

[10] The International Academy of Pathology. (n.d.) IAP Ambassadors. https://www.iapcentral.org/current-activities/iap-ambassadors 